\title{
An Analysis of the Impact of Real Effective Exchange Rate on Economic Growth of Nepal
}

\author{
Sujan Koirala \\ Lecturer, Nepal Commerce Campus
}

\begin{abstract}
This article is designed to assess the impact of real effective exchange rate (REER) on economic growth of Nepal. The study uses annual time series data for the period of 1975 to 2015. EngleGranger residual based test and error correction model have been used to detect the impact of REER on real GDP of Nepal. The explanatory variables used in the study are real effective exchange rate, broad money supply, trade openness and gross fixed capital formation. The results of the study reveal that real effective exchange rate has positive impact on the real GDP of Nepal. Based on the findings, the study concludes that the transmission mechanism of REER through aggregate demand hold in case of Nepal and this result is compatible with the traditional approach to exchange rate. Finally, it is recommended that broad money supply continues to be relevant monetary policy for Nepal. Moreover, Nepal must use the real exchange rate as one of the macroeconomic policies.
\end{abstract}

Key Words: Exchange Rate, Trade Openness, Broad Money Supply etc.

\section{Introduction}

The exchange rate has become a growing focus of attention in the recent policy debate in developing countries. This is mainly due to two reasons. First, with increased emphasis on export-led growth and the dismantling of tariff and non-tariff barriers, the role of the exchange rate in growth and development has gained added importance. Drawing on the experience of late-industrializers in East Asia, competitive and stable exchange rates have come to be seen as a key ingredient of successful industrialization. Second, with rapid liberalization of the capital account in developing countries and the growing size and speed of international capital flows, the impact of ex-change rate swings on economic activity has undergone a fundamental transformation.

The exchange rate system of Nepalese Rupee has been pegged with Indian Rupee, the exchange rate for which is officially determined. On the other hand, India is under the managed floating rate system. The value of Indian Rupee is increasing in recent years. The exchange rate vis-à-vis US dollar has been depreciated because of increase in the US dollar rate. The Indian economy is performing well over the years and the prospect is expected to be better in the years to come, signalling the appreciation of Indian Rupee.

On the other hand, the situation of Nepal is just opposite owing to the deterioration of law and order situation of the country caused by political instability. The economy has been growing by less than 5 per cent. The conventional sources of foreign exchange earnings, that is, tourism is drying up and constant monitoring of the exchange rate 
movement as well as periodic revision in the parity. This is essential not only from the economic perspective but only from the view point of maintaining the confidence by Nepalese in the national currency. It is to be noted that the dual currency system was abolished after 1996 when the Nepalese currency was kept unchanged for a while even after substantial devaluation or revaluation of IC by India. Now the circulation of IC seems to be increasing again. Khatwada (2005) concludes that rather than keeping the exchange rate unchanged for a long period of time and taking pronounced devaluation or revaluation decision, applying due caution to curb the likely speculative tendencies. Even in the present context, one cannot rule out the possibility of speculative motives. The timely revision in NC/IC rate is desirable even for maintaining the Nepalese currency competitive in terms of convertible currencies.

Real exchange rates play a vital role in foreign trade and economic development. It is apparent that changes in real exchange rates (either depreciation or appreciation) have wider and far reaching economic effects. It is therefore very important to understand how exchange rates affect economic growth in Nepal. One of the macro economic objectives of Nepal is to achieve sustainable economic growth. High economic growth helps to maintain an adequate level of foreign reserves and to create and maintain a sustainable, internationally competitive exporting sector that will contribute to job creation and high incomes.

\section{Objective of the Study}

The prime objective of the study is to examine the impact of real effective exchange rate on economic activities of Nepal.

\section{Empirical Review}

A lot of researchers detected the impact of real exchange rate on economic growth using different methods in different countries. They arrived to different conclusions depending on the country, methods and time of study. This section presents the various studies done, the methods used, the countries of research and the results obtained.

Domac and Shabsigh (1999) detected the impact of real exchange rate misalignment on the collective economic growth of Egypt, Jordan Morocco and Tunisia. The study incorporated the three measures of exchange rate misalignment constructed on the basis of purchasing power parity, a black market exchange rate and a structural model. Using the Three Stage Least Square Technique, the study presented that exchange rate misalignment has adverse effect on collective growth. Moreover, the results also demonstrated that the coefficients of other factors like capital growth and population growth are statistically significant with appropriate theoretical signs as mentioned in Solow growth model during the study period of 1979 to 1996.

Acar (2000) assessed the effects of devaluation on output growth in Least Developed Countries. The study used the data for 18 countries in fixed effect procedures. Two separate regression analyses were applied on the basis of the division of LDCs into two different categories. First, the data from a group of 10 countries including both manufacturing product exporters and primary product exporters were incorporated to construct output growth model for a period of 25 years. Second, in order to estimate qualitative difference in terms of the effect of devaluation, the data from different groups of countries including 8 manufacturing product exporters and 8 primary 


\section{Pravaha Journal-2018}

product exporters were also analysed for the periods of 20 years. In addition, the role of monetary, fiscal policies and changes in the terms of trade were also incorporated in the model. The results demonstrated that devaluation had contractionary effect on the output in the first year, while it expansionary effect in the subsequent year. The results also showed that there was no any qualitative difference in terms of the effect of devaluation between manufacturing exporters and agricultural exporters. Finally, expansionary fiscal policy remained significant factor for stimulating output growth for all countries during the entire study period.

Miteza (2006) assessed the impact of changes in real exchange rate on output growth in Bulgaria based on secondary data for the period of 1994 to 2004. Applying Smooth Transition Regression Model, the findings of the study revealed that the appreciation of real exchange rate bears positive impact on economic growth. Furthermore, the results also demonstrated that real exchange rate can only be contractionary if excessive money growth occurs sporadically.

Abida (2011) investigated the relationship between real exchange rate misalignment and long run economic growth in Maghreb countries. Using a dynamic panel growth model, the results indicated that the depreciation of the real exchange rate retards the process of long run economic growth.

Masunda (2011) tested the impact of real exchange rate misalignment on sectoral output growth over the time period from 1980 to 2003 in Zimbabwe. The study employed feasible generalized least squares panel data techniques using data and the results of the study showed that real exchange rate misalignment is disastrous to sectoral output growth. Furthermore, the findings of the study demonstrated that depreciation of real exchange rate negatively affects the sectoral output.

In similar fashion, Chen (2012), using the date for the period of 1992 to 2008, also examined the role of the real exchange rate in economic growth and in the convergence of growth rates among provinces in China. Employing the generalized method of moments and the results of the study show that real exchange rate appreciation has positive influence on economic growth in the 28 provinces.

Akpan et al. (2012), based on quarterly time series data for the period 1986 to 2010, examined the relationship exchange rare movement and output growth in Nigeria. Using Generalized Method of Moments (GMM) technique, the findings of the study revealed that there is strong and direct impact of changes in the exchange rate on output.

Akpan et al. (2012), based on quarterly time series data for the period 1986 to 2010, examined the relationship exchange rare movement and output growth in Nigeria. Using Generalized Method of Moments (GMM) technique, the findings of the study revealed that there is strong and direct impact of changes in the exchange rate on output.

Pal(2014), using the data for the period of 1970-2006, examined the impact of real exchange rate, inflation, US interest rates, foreign exchange reserves and government expenditures on real per capita GDP growth in India. Using a smooth transition regression model, the study found that appreciations of real exchange rate have positive effects on growth.

In the context of Nepal, Thapa (2002) examined the relationship between real effective exchange rate and GDP on Nepalese economy. The study used secondary 
data for the period of 1978 to 2000. Employing regression analysis, the findings of the study reveal that international competitiveness represented by real effective exchange rate (REER) is statistically significant in and exhibits negative association with GDP of Nepal. This means that depreciation of Nepalese currency boosts up international competitiveness through the expansion of exports. The study concluded that real exchange rate operates through aggregate demand channel and this result is compatible with the traditional view.

\section{Research Gap}

This study modifies the model by Acar (2000). Acar, in his model, has used economic growth as a proxy variable represented by GDP as a dependent variable determined by the changes in the directions and magnitudes of the explanatory variables such as real effective exchange rate, terms of trade, government expenditure and money supply. For the purpose of the present study, trade openness has replaced the terms of trade and government expenditure has been dropped. However, gross fixed capital formation has been added as the explanatory variables in the model.

\section{Methodology}

This section sets the analytical foundation used in this study by providing the modified model employed to empirically assess the impact of real effective exchange rate on economic growth in Nepal from 1975 to 2015. This section also includes availability of data sources, research techniques and test of stationarity followed by co-integration test and error correction model.

\section{Data Sources}

This study uses time series annual data covering the period of 1975-2015. GDP, gross fixed capital formation is obtained from Economic Surveys, the Ministry of Finance, money supply, exchange rates and trade figures are obtained from the Nepal Rastra Bank (NRB) publications and International Financial Statistical Year Book.

\section{Calculation of Real Effective Exchange Rate}

It is quite evident that Nepal quotes both buying and selling rates of NC with twenty foreign currencies. Since nominal exchange rate between NC and IC is pegged, nominal exchange rates of NC with other countries are subject to change on the basis of market mechanisms. For the purpose of the present study, Nominal Exchange Rate Index (NERi) is constructed in terms of foreign currency value quoted in local currency. Then, the next process is to construct Real Exchange Rate Indices (RERi) of NC with foreign currencies by taking price differential of Nepal with those currencies' countries. In this study, a rise in the RERi indicates a nominal depreciation of the local currency in terms of foreign currencies. Finally, a composite index is constructed for the purpose of the study i.e. real effective exchange rate. The procedures involved in the calculation of REER are as follows:

The first step involves the calculation of nominal exchange rate index (NERi)

$\mathrm{NERi}=1 /$ nominal rate of foreign currency unit quoted in local currency value (1)

Here, NERi refers to units of foreign currency divided by the units of local currency value of those of foreign currency. 


\section{Pravaha Journal-2018}

Following the first step, the next step encompasses the computation of real exchange rate index (RERi) by using following formula.

$\mathrm{RERi}=\mathrm{NERi} *(\mathrm{Pf} / \mathrm{P})$

The final step involves the calculation of real effective exchange rate index (REERi). This step adjusts trade weights on the basis of respective real exchange rate indices.

Although Nepal has trade relationship with a number of countries, there are numerous difficulties encountered in the construction of a comprehensive REER index. First, Nepal's trade with most of the countries is insignificant. Hence, there is meaningless to calculate the RER of NC with those countries for the purpose of study. Similarly, another difficulty arises due to the unavailability of accurate time series data of trade with all trade partners countries separately. Due to these limitations, the NER and RER indices are constructed with respect to IC and US dollar. Since India is a major trade partner, the share of trade with India constitutes almost 60 per cent of total trade. On the other hand besides India, most of the trade of Nepal with rest of the world is carried through the US dollar. Hence, besides IC, the NER and RER indices are also constructed with respect to the US dollar. However, this study tries to assess the impact of real exchange rate on economic growth in both IC and US dollar separately too. Finally, identity (2) is used in the calculation of REER.

REERiW = RERiW * TWW.

Where, REERiW = Real effective exchange rate index of NC with US dollar

TWW $=$ Nepal's trade weight (share) with rest of the world

REERiI $=$ RERiI * TWI.

Where, REERiI = Real effective exchange rate index of NC with IC

TWI = Nepal's trade weight (share) with India

Hence, the composite index of real effective exchange rate is given by,

$\mathrm{REER}=\Sigma(\mathrm{RERiW} * \mathrm{TWW}+\mathrm{REERI} * \mathrm{TWI})$

Since consumer price index for the three countries is constructed considering $2009 / 10$ as a base year, then real effective exchange rate index (REERI) is also constructed considering the same base year.

\section{Model Specification}

To analyze the impact of real effective exchange rate on economic growth in Nepal, the explanatory variables incorporated in this study are gross fixed capital formation, trade openness, broad money supply and real effective exchange rate.

The present study adapts the model formulated by Acar. 'The reduced form equation for output in this model is formally specified below '(Sibanda, 2005).

$\mathrm{LnYt}=a+\mathrm{YT}+B 2 \mathrm{Gt}+82 \Delta \mathrm{Msf}+B 4 \mathrm{TTt}+B 5 \mathrm{Et}+\varepsilon \mathrm{t}$.

Where,

$\mathrm{Yt}=$ Real output

$\mathrm{Y}=$ Parameter that captures the trend rate of growth

$\mathrm{T}=$ Time period

$\mathrm{G}=$ Relative size of the government

$\mathrm{Ms}=$ Money supply

$\mathrm{TT}=$ Terms of trade

$\mathrm{E}=$ Real exchange rate 
$\varepsilon=$ Error term with zero mean and constant variance

The primary objective of this study is to empirically assess the impact of the real exchange rate on real GDP of Nepal. To achieve this objective, output growth model has been formulated by including the real effective exchange rates (REER) as an additional variable to the set of explanatory variables. In this study, the dependent variable is real GDP (RGDP) as determined by the movements in other explanatory variables such as gross fixed capital formation (GFCF), broad money supply ( M2 ), trade openness ( OPEN ) and real effective exchange rate (REER ) which is regarded major explanatory variable for the purpose of the present study. Based on this information, following model has been developed:

RGDP $=\omega 0+\omega 1$ RGEX $+\omega 2$ RM $2+\omega 3 \mathrm{REER}+\omega 4 \mathrm{RGFCF}+\omega 5 \mathrm{OPEN}+\omega 6 \mathrm{RTX}$

In order to obtain elasticity coefficients, the variables have been transformed into logarithms, the log linear form of the functions becomes,

LnRGDPt $=\omega 0+\omega 1$ LnREERt $+\omega 2$ LnOPENt $+\omega 3$ LnRM2t $+\omega 4$ LnRGFCFt + Ut....(9)

Where,

RGDPt= Current level of real gross domestic product (a proxy for national output)

REERt $=$ Current level of real effective exchange rate

$\mathrm{M} 2 \mathrm{t}=$ Current level of real broad money supply

OPENt $=$ Current level trade openness

RFFCt $=$ Current level of real gross fixed capital formation

Q1............. $=$ Parameters to be estimated and tested

\section{Empirical Analysis}

Undoubtedly, time series econometric study remains incomplete without performing stationary test on variables used for the study. Regression run on nonstationary time series variables is meaningless as it produces spurious results due to high R2 and low D.W.value. Hence it is essential to ensure that variables are stationary. This means that 'a stationary time series has three characteristics namely finite mean, variance and auto-covariance overtime'(Gujrati, 2004, p.797). At present, two tests available to examine whether the time series variables are stationary or not. Two tests involved are: (i) the correlogram method and (ii) the unit root method.

The unit root test is widely used as formal statistical tests than correlogram. Dicky-Fuller (DF) and Augmented Dicky-Fuller (ADF) are widely used tests. To apply these unit root tests, consider the following equation.

$\mathrm{Yt}=\mathrm{a}+\mathrm{p}$ Yt -1

The time series $\mathrm{Y}$ is considered stationary if $\mathrm{p}$ lies between -1 to 1 . On the other hand if $\mathrm{p}$ equals or greater than one then the time series is non-stationary. For time series to be stationary, the value of $p$ must be less than one. Hence, an unit root of the series indicates the null hypothesis of unit root test. Symbolically,

$\mathrm{H} 0=1$

Alternatively, the unit root test measures the following process.

$\Delta \mathrm{Yt}=\mathrm{a}+\delta \mathrm{Yt}-1+\mathrm{Ut}$

Where, $\delta=\mathrm{p}-1$

$\Delta=$ Difference operator 
In this context, the null hypothesis is that $\delta$ has zero value. Symbolically,

Ho: $\delta=0$

$\delta$ will be zero in case of the value of p equals to 1 and $\delta$ will be positive and greater than zero in case of the value $p$ exceeds 1 . When the value of $p$ exceeds one, then the time series becomes explosive. It is evident that the value of $\mathrm{p}$ should not exceed one for the time series to be stationary. It means that the coefficient of $\delta$ must be negative with the corresponding negative ADF t- statistics and MacKinnon critical values.

\section{Co-integration Test}

This step is used to find out to test whether two or more variables are co-integrated or not. The test is useful for establishing a long-run relationship between time series macroeconomic variables, as most of the macroeconomic variables, are non-stationary in their levels, trend over time and seem to follow random walk. Co-integration technique provides a means to avoid the non-stationary time series generated spurious regressions.

To test whether any long run equilibrium relationship would exist among the six variables, Engle - Granger two steps had to be followed:

Engle and Granger suggest a co-integration test, which involves two steps. The first step is concerned with estimating the Co-integration regression by OLS, obtaining the residual ût, while the second step involves performing unit root test for ût. To ascertain an equilibrium situation, they suggest testing the null hypothesis that ût has a unit root against the alternative hypothesis that it has a root less than unity. Since ûtare estimated, new response surface critical values need to be tabulated.

$\mathrm{ut}=\rho+\mathrm{ut}-1+\varepsilon \mathrm{t}$

With $\varepsilon t \sim$ i.i.d. $(0, \sigma 2)$

One could assume three possibilities, that $\rho$ is smaller, equal or higher than one:

If $\left|\rho^{\wedge}\right|>1: y t \sim \mathrm{I}(1)$ and $\mathrm{xt} \sim \mathrm{I}(1)$ then $\mathrm{ut} \sim \mathrm{I}(2)$,

If $|\rho \wedge|=1: y t \sim \mathrm{I}(1)$ and $\mathrm{xt} \sim \mathrm{I}(1)$ then $\mathrm{ut} \sim \mathrm{I}(1)$,

If $\left|\rho^{\wedge}\right|=1: y t \sim \mathrm{I}(1)$ and $\mathrm{xt} \sim \mathrm{I}(1)$ then $\mathrm{ut} \sim \mathrm{I}(0)$,

Only if $\left|\rho^{\wedge}\right|<1$, a co-integration relationship exists.

\section{Error Correction Model}

Co-integration is concerned with restoration of equilibrium of the variable in long run if there is deviation in the short run. The error correction model is specified below:

DLnRGDPt $=\omega 0+\omega 1$ ECT $(-1)+\omega 2$ DLnREERt $+\omega 3$ DLnOPENt $+\omega 4$ DLnRM $2 t+$ $\omega 5$ DLnRGFCFt+ Ut....(9)

Where, ECT $(-1)=$ One Year Lag of Error Correction Term

$\mathrm{D}=$ First Difference

Table 1: Stationary Test: Unit Root Test

\begin{tabular}{llllll}
\hline & & \multicolumn{3}{c}{ ADF Test } & \multicolumn{3}{c}{ Mackinon Critical Value } \\
\hline \multicolumn{1}{c}{ Variable } & \multicolumn{1}{c}{ Statistics } & $1 \%$ & $5 \%$ & $10 \%$ \\
\hline & LNRGDP without C and T & 3.1243 & -2.624 & -1.949 & -1.612 \\
1. & LNRGDP with C & 0.1772 & -3.606 & -2.937 & -2.607 \\
& LNRGDP with C and T & $-7.2916^{*}$ & -4.205 & -3.527 & -3.195 \\
\hline
\end{tabular}


Pravaha Journal-2018

\begin{tabular}{|c|c|c|c|c|c|}
\hline & \multirow[b]{2}{*}{ Variable } & \multirow{2}{*}{$\begin{array}{c}\text { ADF Test } \\
\text { Statistics }\end{array}$} & \multicolumn{3}{|c|}{ Mackinon Critical Value } \\
\hline & & & $1 \%$ & $5 \%$ & $10 \%$ \\
\hline \multirow{5}{*}{2.} & $\Delta$ LNRGDP with $\mathrm{C}$ & $-8.7258^{*}$ & -3.610 & -2.939 & -2.608 \\
\hline & LNRM2 without $\mathrm{C}$ and $\mathrm{T}$ & 7.9368 & -2.624 & -1.949 & -1.612 \\
\hline & LNRM2 with C & -0.3577 & -3.606 & -2.937 & -2.607 \\
\hline & LNRM2 with $\mathrm{C}$ and $\mathrm{T}$ & $-3.4075^{* * *}$ & -4.205 & -3.527 & -3.195 \\
\hline & $\Delta \mathrm{LNRM} 2$ with $\mathrm{C}$ & $-7.0235^{*}$ & -3.610 & -2.939 & -2.608 \\
\hline \multirow{4}{*}{3.} & LNREER without $\mathrm{C}$ and $\mathrm{T}$ & 0.5789 & -2.624 & -1.949 & -1.612 \\
\hline & LNREER with C & -2.4115 & -3.606 & -2.937 & -2.607 \\
\hline & LNREER with $\mathrm{C}$ and $\mathrm{T}$ & -1.3684 & -4.205 & -3.527 & -3.195 \\
\hline & $\triangle$ LNREER with C & $-6.5100^{*}$ & -3.610 & -2.939 & -2.608 \\
\hline \multirow{4}{*}{4.} & LNRGFCF without $\mathrm{C}$ and $\mathrm{T}$ & 3.7942 & -2.624 & -1.949 & -1.612 \\
\hline & LNRGFCF with C & 0.1024 & -3.606 & -2.937 & -2.607 \\
\hline & LNRGFCF with $\mathrm{C}$ and $\mathrm{T}$ & $-3.4883^{* * *}$ & -4.205 & -3.527 & -3.195 \\
\hline & $\triangle \mathrm{LNRGFCF}$ with $\mathrm{C}$ & $-8.4811^{*}$ & -3.610 & -2.939 & -2.608 \\
\hline \multirow{4}{*}{5.} & LNTOPEN without $\mathrm{C}$ and $\mathrm{T}$ & $-1.9388^{* * *}$ & -2.624 & -1.949 & -1.612 \\
\hline & LNTOPEN with C & -1.6871 & -3.606 & -2.937 & -2.607 \\
\hline & LNTOPEN with $\mathrm{C}$ and $\mathrm{T}$ & -1.9379 & -4.205 & -3.527 & -3.195 \\
\hline & $\triangle \mathrm{LNTOPEN}$ with $\mathrm{C}$ & $-6.9108^{*}$ & -3.610 & -2.939 & -2.608 \\
\hline
\end{tabular}

Note.*indicates level of significance at 1percent or less

**indicates level of significance at 5percent or less

$* * *$ indicates level of significance at 10 percent or less

Having established that all the variables are non-stationary at first difference, the study has conducted the Engle-Granger's (EG) residual-based ADF test. As the first step of the EG co-integration test, the study has estimated co-integrating equation using the OLS method. Table 2 reveals Engle- Granger residual based test results.

Table 2: Engle - Granger Co-integration Test (First Step)

\begin{tabular}{lccc}
\hline \multirow{2}{*}{ Variables } & \multicolumn{3}{c}{ Dependent Variable: RGDP } \\
\cline { 2 - 4 } & Coefficient & t- statistics & P- Value \\
\hline CNRM2 & $5.8058^{*}$ & 12.0139 & 0.0000 \\
LNREER & $0.3535^{*}$ & 4.5212 & 0.0001 \\
LNTOPEN & 0.1049 & 1.5949 & 0.1195 \\
LNRGFCF & -0.0838 & -0.8143 & 0.4208 \\
R2 & $0.3165^{*}$ & 2.4549 & 0.0191 \\
F - Statistic & 0.99 & \\
D.W. & $650.0791^{*}$ & \\
Note.*indicates level of significance at 1percent or less \\
$* *$ indicates level of significance at 5percent or less \\
$* * *$ indicates level of significance at 10percent or less
\end{tabular}

The Engle Granger co-integration test carried suggests that there is long-run relationship between RGFCF and RM2 and Real GDP in Nepal. The R2 
which is called the coefficient of determination gives the adequacy of the model. The value of $\mathrm{R} 2$ is 0.99 that means the independent variable in the model can predict 99 percent of the variance in dependent variable. The value of DurbinWatson statistics of 1.12 is slightly low which indicates that the equation is not free from autocorrelation in our study and the regression models assume that the error deviations are correlated.

The results of regression show that the coefficients RGFCF and RM2 are statistically significant in explaining the economic activities of Nepal. In contrary to the other variables, the trade openness, though statistically insignificant, has negative relationship with real GDP of Nepal. It implies that trade openness is not an attributing factor for enhancing economic activities of Nepal due to low export base, lack of quality products, high cost of production, difficulties encountered in transit facilities etc.

The second step of the Engle and Granger procedure is used to check the stationarity of residuals by performing the ADF test. Table 3 presents the results from Engle-Granger (EG) co-integration test.

Table 3: Engle Granger Co-integration Test (Second Step)

\begin{tabular}{lccc}
\hline \multicolumn{1}{c}{ Variable } & ADF t- statistics & Response Surface Estimates of Critical Values \\
\hline ECT(01) without C and T & $-4.999^{* *}$ & -5.017 & $1 \%$ \\
ECT(01) with C & $-4.9451^{* *}$ & -4.324 & $5 \%$ \\
ECT(01) with C and T & $-5.0113^{* *}$ & -3.979 & $10 \%$ \\
\hline
\end{tabular}

Note. ${ }^{* * i n d i c a t e s ~ l e v e l ~ o f ~ s i g n i f i c a n c e ~ a t ~} 5$ percent or less

From the above results, the ADF test statistic is greater than the response surface estimates of critical values at less than 5 percent and then the study accepts $\mathrm{H} 1$ and concludes that the series is co-integrated. In other words there is long-run relationship between the real GDP and the independent variables under consideration. Table 4 presents the results of error correction model with overall case as follows:

Table 4: Error Correction Model Results

\begin{tabular}{lccc}
\hline \multirow{2}{*}{ Variables } & \multicolumn{3}{c}{ Dependent Variable: DRGDP } \\
\cline { 2 - 4 } & Coefficient & t- statistics & P- Value \\
\hline E & 0.0150 & 1.2393 & 0.2237 \\
DLN01(-1) & $-0.7145^{*}$ & -5.1287 & 0.0000 \\
DLNRM2 & $0.1567^{* * *}$ & 1.6914 & 0.0999 \\
DLNRGFCF & $0.2709^{* *}$ & 2.3476 & 0.0222 \\
DLOGTOPEN & $0.1446^{*}$ & 1.5982 & 0.0145 \\
R2 & $0.1443^{* *}$ & 1.1619 & 0.0249 \\
D.W. & 0.68 & & \\
F Value & 1.84 & & \\
\hline
\end{tabular}

Note.*indicates level of significance at 1 percent or less

**indicates level of significance at 5 percent or less

$* * *$ indicates level of significance at 10 percent or less 
The result of ECM shows a negative and significant coefficient of lagged residual. This means that if there is deviation from equilibrium, 71percentis corrected in every year as the variable moves towards obtaining original equilibrium. It indicates that real GDP has significant pressure to restore long run equilibrium as it deviates from equilibrium position. This speed of adjustment is, however, statistically significant even at less than 1percent. The high speed of adjustment by real GDP may reflect that major factors affecting real GDP in Nepal which have been incorporated in the model. All the variables incorporated in the model are statistically significant in explaining the real GDP in short run. However, the statistical significance of the coefficients of RM2, RGFCF and REER shows the positive association with real GDP of Nepal through aggregate demand channel. REER, the main explanatory variable in the study, bears the positive impact on the economic activities of Nepal in both long run and short run. It means an increase in real effective exchange rate which is the depreciation of Nepalese currency promotes economic growth through enhancing the international competitiveness. This result coincides with the traditional approach to exchange rate. According to traditional view, the depreciation has expansionary effects on economic growth through aggregate demand channel. It is in the sense that depreciation of a currency will make domestic goods relatively cheaper in international market and this will enlarge the frontier of exports. With the rise in exports, eventually balance of payment difficulties is corrected.

\section{Conclusion}

The long run results of the model show that RGFCF and RM2 have a long run relationship with real GDP. However, both short run and long run dynamic relationship reveal that the negative coefficient of TOPEN indicating that trade openness does not seem to be instrumental for enhancing economic activities of Nepal due to low export base, lack of quality products, high cost of production, difficulties encountered in transit facilities etc. Similarly, the significance of the coefficient of RGFCF in both short run and long run emphasizes the role of investment in infrastructure development in boosting up the economic growth of Nepal.

Finally, it is quite evident from the study that gross fixed capital formation and broad money have remained key instrument in promoting the economic development of Nepal. It can be taken for granted from this study is that broad money supply continues to be relevant monetary policy variables respectively for Nepal. Moreover, Nepal must use the real exchange rate as one of the macroeconomic policies.

\section{References}

Acar, M.(2000). Devaluation in developing Countries: Expansionary or contractionary? Journal of Economic and Social Research, 2 (1),59-83.

Abid, Z. (2011). Real exchange rate misalignment and economic growth: an empirical evidence for the Magherb Countries. International Journal of Economics and Finance. Vol.3(3), 190-201.

Akpan, O.E., \& Atan, A.J.(2012). Effects of exchange rate movements on economic growth in Nigeria. CBN Journal of Applied Statistics. Vol.2(2), 8-14.

Chen, J. (2012). Real exchange rate and economic growth: Evidence from Chinese provincial data (1992-2008). Paris School of Economics, France Working paper 201205. Retrieved from https://hal.archives-ouvertes.fr/halshs 


\section{Pravaha Journal-2018}

Domac, I., \& Shabsigh, G. (1999). Real exchange rate behaviour and economic growth: Evidences from Egypt, Jordan, Morocco and Tunisia.IMF Working Paper, WP/99/40.

Gujarati, D. N. ( 2004). Basic econometrics.4thed. New York: McGraw Hill.

Khatiwada, Y. R. (2005). Monetary policy. Macroeconomy, Part III. Nepal Rastra Bank in Fifty Years.

Masunda, S. ( 2011). Real exchange rate misalignment and sectoral output in Zimbabwe. Midlands State University, Zimbabwe. Working Paper. Retrieved from

Miteza, I. (2006). Exchange rates and non-linear dynamics in output: evidence from Bulgeria. Journal of Economics and Business. Vol.9(1),91-115.

MOF (Ministry of Finance) (2013).Economic survey fiscal year 2012/13. Nepal: Government of Nepal.

MOF (Ministry of Finance) (2014). Economic survey fiscal year 2013/14. Nepal: Government of Nepal.

MOF (Ministry of Finance) (2015). Economic survey fiscal year 2014/15. Nepal: Government of Nepal.

NRB (Nepal Rastra Bank) ( 2015).Quartely economic bulletin. Vol.49, No.4; Mid-July 2015.

Pal, S.(2014). Real exchange rate effects on output in India. Journal of Quantitative Economics. Vol.12(1), 168-174.

Sibanda, K. (2012). The impact of real exchange rates on economic growth: a case study of South Africa.

Unpublished M.Com Thesis, University of Fort Harare.

Thapa, N. B. (2002).An econometric analysis of the impact of real effective exchange rate on economic activity of Nepal. Economic Review Occasional Paper. Vol.14,17-26. 